\title{
LA ABOMINABLE CARGA DEL YO
}

Claudia Solanlle Gordillo Aldana ${ }^{1}$

¿yo? Así termina la primera opera prima del cineasta colombiano Felipe Rugeles. Doble yo (2018) es una película documental experimental que usa, principalmente, materiales de archivo grabado por el antropólogo y arqueólogo colombiano Gregorio Hernández de Alba (1904-1973) durante sus expediciones etnográficas a regiones colombianas como la Guajira y Tierradentro entre 1935 y 1942. Hernández de Alba, luchador de la causa indigenista, grabó, fotografió y escribió cuadernos de campo obsesivamente que dan cuenta del uso de la imagen en su trabajo desde una mirada de la etnografía visual. Esas imágenes y sonidos nos aproximan a las formas de cómo los europeos construyeron la idea del salvaje, a las estrategias de colonización de los cuerpos, a las formas de dominación de las creencias, a la institucionalización y naturalización de las violencias en Colombia que pasaron por el exterminio de poblaciones indígenas a manos de los españoles, los terratenientes y los misioneros. Ellos no solo robaron sus tierras, violaron a sus mujeres, mataron a sus hombres sino que construyeron una idea de verdad para los blancos en la que se legitimó la "limpieza" de las características salvajes y caníbales.

Esta historia de "colonización", precariedad y violencia es contada a través de las voces del antropólogo Gregorio mediante sus materiales de archivo; su hijo Carlos quien heredó, tras la muerte de su padre, cajas con películas, negativos, fotografías y recortes de prensa que con voz anecdótica relata sus recuerdos; Pero López quien encarna un personaje imaginario de la conquista española, dejado en libertad con la condición de ser embarcado en el navío que vendría a las Américas y que hace parte de la fabula ficcional que retoma Rugeles de la radionovela Estampas de la conquista escrita por Gregorio a finales de los años 30,

\footnotetext{
${ }^{1}$ Universidad Central, Colômbia. Email: claudia.gordilloa@gmail.com ORCID id: https://orcid.org/0000-0002-2444-1316
} 
personaje que hace un recorrido por Tierradentro en la actualidad; y, finalmente la voz reflexiva de Felipe Rugeles, el director de la película y amigo de la familia a través de su tío Roberto, otro antropólogo.

Estos cuatro personajes entretejen la historia de la vida cotidiana y profesional de quien fue un expedicionario cultural indigenista mediante la narración de tres expediciones relevantes: la primera, realizada en 1935 a la Guajira, norte de Colombia, en la que acompañó a la primera comisión norteamericana de antropólogos en Colombia, quienes estaban interesados en conocer la cultura de los indígenas Wayú, convirtiéndose, así, en el primer antropólogo colombiano representante del gobierno para vigilar la labor de los profesores universitarios extranjeros; la segunda, en 1936 a San Agustín y Tierradentro, Huila, siendo esta la segunda visita del antropólogo pero la más importante en los recuerdos de Carlos, su hijo, ya que llevó a su familia a conocer los vestigios arquitectónicos, artísticos y rituales de los indígenas paez y el Desierto de la Tatacoa; y la tercera y última expedición, a Tierradentro en 1942 dedicada al conocimiento de las costumbres de los paeces.

En el relato de cada expedición se entretejen imágenes de archivo de súper 8, películas, carretes, fotos, titulares de periódicos, notas de campo, documentos oficiales en blanco y negro y a color, material recuperado que aparece con efecto de desgastado, de corroído, de saturado, donde los vestigios del tiempo insisten con aruñazos sobre la imagen para no caer en el olvido. Con efectos de sobreposición, repetición, mosaico, apariciones, recorte de elementos, grabación de las grabaciones y proyección de las imágenes para trabajarlas como sombras hacen de este documental una experiencia laberíntica, donde el ojo va y viene sobre los elementos que aparecen como síntomas en la narración. Ello se enlaza con grabaciones sonoras, radionovela, entrevistas, voz reflexiva, música y silencios, donde pareciera, en ciertos momentos, que el documental extrapola los sentidos, los altera intencionalmente para colocar como premisa que la "colonización" fue un exabrupto ejecutada por miles de Pero López que conforman la escoria española. 
Así como el documental tensiona conceptos como pureza, nacionalismo, salvaje, blanco y conquista española, también denuncia a terratenientes, misioneros y conservadores por la persecución a los indígenas, a sus tierras, a sus creencias y a sus costumbres, activando un tipo de "guerra contra los bárbaros" que tenía como objetivo el adoctrinamiento de los indígenas en todas sus formas. Acciones que fueron establecidas no solamente con planes propagandísticos, de empobrecimiento y de destierro, sino de matanzas y de amedrentamiento sistemático mediante las acciones de Los Pájaros, el primer grupo paramilitar al servicio de los aliados conservadores en la época de la Violencia, quienes degollaban a los paeces con alambres de púa para dejar sus cabezas en los caminos. Así, como también quemaban casas, instalaban bombas y amenazaban a la población.

Doble yo, es un documental de fabulas de un recuerdo sobre otro recuerdo que va tejiendo la historia abominable de la "conquista española", el exterminio y el adoctrinamiento indígena que pretende incomodar a los espectadores sobre el lugar de su yo, un doble yo que se disputa entre lo que se era y lo que se es. Un yo que interroga la relación con el futuro: ¿yo?

Recebido: $10 / 02 / 2020$

Aprovado: 15/07/2020 